\begin{tabular}{|c|} 
Jurnal Keolahragaan \\
Volume 4 - Nomor 2, September 2016, (122-134) \\
Tersedia online: http://journal.uny.ac.id/index.php/jolahraga
\end{tabular}

\title{
PENGARUH METODE LATIHAN DAN KOORDINASI TERHADAP SMASH BACKCOURT ATLET BOLA VOLI YUNIOR PUTRA
}

\author{
Agung Kristriawan $^{1} *$, Sukadiyanto ${ }^{2}$ \\ ${ }^{12}$ Program Studi Ilmu Keolahragaan, Program Pascasarjana, Universitas Negeri Yogyakarta. Jalan \\ Colombo No 1, Karangmalang, Yogyakarta 55281, Indonesia \\ * Korespondensi Penulis. Email: agoenk_ney@yahoo.com
}

Received: 16 September 2016; Revised:11 October 2016; Accepted: 31 October 2016

\begin{abstract}
Abstrak
Penelitian bertujuan mengetahui: (1) pengaruh antara metode latihan sederhana dan metode latihan kompleks terhadap smash backcourt, (2) pengaruh antara koordinasi tinggi dan koordinasi rendah terhadap smash backcourt, dan (3) interaksi antara metode latihan dan koordinasi terhadap hasil smash backcourt. Metode penelitian eksperimen dengan desain faktorial 2 x 2. Populasi penelitian adalah atlet Klub Bola Voli yunior putra Yuso Sleman dan atlet Klub bola voli yunior putra Yuso Gunadarma. Instrumen yang digunakan adalah instrumen tes koordinasi mata-tangan dan test smash Laveage. Teknik analisis data yang digunakan adalah ANAVA. Hasil penelitian ini menunjukkan bahwa: (1) ada perbedaan pengaruh yang signifikan antara metode latihan sederhana dan metode latihan kompleks terhadap hasil smash backcourt, (2) ada perbedaan pengaruh yang signifikan antara atlet yang mempunyai koordinasi tinggi dan koordinasi rendah terhadap hasil smash backcourt, dan (3) terdapat interaksi antara metode latihan dan koordinasi terhadap smash backcourt.
\end{abstract}

Kata Kunci: metode latihan sederhana, metode latihan kompleks, koordinasi, smash backcourt, bola voli.

\section{THE EFFECT OF EXERCISE METHOD AND COORDINATION ON THE SMASH BACKCOUT OF JUNIOR ATHLETES}

\begin{abstract}
This study aimed to determine: (1) the effect between simple exercise and complex exercise method on the smash backcourt, (2) the effect between the high coordination and low coordination on the smash backcourt, and (3) the interaction between exercise method and coordination on the smash backcourt. The research is experimental with $2 \times 2$ factorial design. The population of the research was Volleyball Club Yuso Junior Sleman and Volleyball Club Yuso Junior Gunadarma. The samples were taken with purposive sampling technique. The data were collected through eye-hand coordination test and smash Laveage test modification. The data analysis technique used is the variant analysis (ANOVA). The results of this study indicate that: (1) there is a significant difference between simple exercise method and complex exercise method, (2) there is a significant difference between athletes with high coordination and low coordination, and (3) there is an interaction between exercise method and coordination against smash backcourt.
\end{abstract}

Keywords: simple method, complex method, coordination, smash backcourt, volley ball.

How to Cite: Kristriawan, A., \& Sukadiyanto, S. (2016). Pengaruh metode latihan dan koordinasi terhadap smash backcourt atlet bola voli yunior putra. Jurnal Keolahragaan, 4(2), $122 \quad$ - 134. doi:http://dx.doi.org/10.21831/jk.v4i2.10890

Permalink/DOI: http://dx.doi.org/10.21831/jk.v4i2.10890 


\section{PENDAHULUAN}

Permainan bola voli merupakan salah satu cabang olahraga yang banyak digemari oleh masyarakat Indonesia, karena cabang olahraga ini dapat dilakukan dari anak-anak hingga orang dewasa, baik laki-laki maupun perempuan serta dapat dilakukan di lapangan terbuka maupun lapangan tertutup. Permainan yang terutama menggunakan tangan ini dilakukan hampir semua kalangan, dari masyarakat pedesaan sampai perkotaan. Perkembangan bola voli sangat pesat, ditandai dengan munculnya berbagai klub bola voli di Indonesia pada umumnya dan klub bola voli di Yogyakarta pada khususnya. Klub bola voli di Yogyakarta antara lain seperti GeLighting, Baja 78, Samudra, Raja Wali, Gajah Loka, Pervas, Garuda, Ganevo, Pendowo, Pervoc, Bima Sakti, Wisnu Putra, Spirit, Padmanaba, Raseko, Yuso Gunadarma dan Yuso Sleman.

Permainan bola voli merupakan permainan beregu menggunakan bola besar yang dimainkan oleh dua regu saling berhadapan, masing-masing regu terdiri atas 6 orang, setiap regu diperbolehkan memainkan bola di daerah pertahanannya sebanyak-banyaknya tiga kali pukulan, setiap regu berusaha menempatkan bola di daerah lawan agar mendapat angka/ poin, regu yang pertama mencapai angka 25 adalah regu yang menang. Dalam permainan bola voli dikenal istilah rally, regu yang memenangkan sebuah rally memperoleh satu angka (rally point system), apabila tim yang sedang menerima servis memenangkan rally, akan memperoleh satu angka dan berhak untuk melakukan servis. Pengertian bola voli juga dikemukakan oleh Marques (2009, p.1): "volleyball is a team sport played at all competitive levels (e.g., youth, olympic, and professional) and places an emphasis on explosive movements such as jumping, hitting, and blocking"

Dalam permainan bola voli mempunyai teknik-teknik dasar, menurut Faruq (2009, p.48) teknik dasar dalam permainan bola voli adalah: (1) service (pukulan untuk memulai permainan), (2) passing, yang terdiri atas passing bawah dan passing atas (cara mengoper bola), (3) spike/smash (pukulan ke daerah lawan) dan (4) block (bendungan). Tujuan utama dari teknik tersebut untuk membuat serangan sebaik mungkin, sehingga dengan serangan yang baik diharapkan akan menghasilkan angka untuk tim penyerang. Untuk memudahkan dalam menca- pai tujuan permainan bola voli yaitu dengan melakukan variasi serangan, baik dari garis serang, garis belakang atau bahkan dari daerah service. Salah satu teknik yang sering digunakan untuk menyerang dalam permainan bola voli yaitu dengan teknik smash. Teknik smash merupakan suatu teknik pukulan dalam permainan bola voli di mana tangan mengenai bola secara keras pada bagian atas, sehingga bola melaju dengan kecepatan tinggi dan akan mencapai hasil yang optimal untuk meraih angka jika pemain lawan tidak dapat mengantisipasi bola tersebut. Hal tersebut didukung oleh pendapat Faruq (2009, p.55) smash yaitu memukul bola ke arah lawan sehingga bola bisa melewati net dan tidak dapat dikembalikan oleh lawan, dan tim pemukul bola mendapatkan poin. "Karakteristik bola smash dalam permainan bola voli adalah menukik dan tajam" Ma'mun \& Subroto (2001, p.65). Pendapat tersebut menegaskan bahwa smash merupakan cara utama yang sering digunakan untuk mendapatkan angka atau poin, jadi smash merupakan usaha mencapai kemenangan dalam permainan bola voli. Keberhasilan dalam melakukan smash diperlukan ketepatan yang sistematis, terarah dan terencana serta penerapan prinsip-prinsip latihan yang benar.

Menurut Chen \& Huang (2008, p.4) "...The back-row spike plays an important role for winning the game, the player can improve of back-row spike technique by training, the whole attacking power during the game will be enhanced". Artinya smash backcourt/back-row mempunyai peran penting untuk memenangkan suatu pertandingan. Pemain dapat mengembangkan teknik smash backcourt/back-row dengan latihan. Hasil latihan smash backcourt yang baik merupakan kekuatan besar dalam melakukan penyerangan pada suatu pertandingan. Smash backcourt yaitu smash yang dilakukan dengan awalan di belakang garis serang dan biasanya dilakukan oleh pemain belakang. Tujuan smash backcourt untuk menghindari block dari pemain lawan. Hasil smash backcourt memiliki ruang bola yang lebih luas daripada smash lainnya yang dilakukan di dekat net atau di daerah penyerangan, dengan ruang bola hasil smash backcourt yang lebih besar maka seorang smasher lebih mudah mengarahkan bola pada area yang sulit dijangkau pemain lawan, selain itu ruang bola hasil smash backcourt yang besar akan membuat pemain lawan kesulitan dalam membendung bola. 
Teknik smash backcourt saat ini masih jarang sekali yang menggunakannya apalagi di kalangan atlet yunior, sebagian besar penyerangan yaitu menggunakan smash di depan garis serang. Hal tersebut berdasarkan observasi yang dilakukan pada kejuaraan daerah antar club yunior se-DIY bahwa kurang dari $4 \%$ atlet yunior melakukan smash backcourt dalam setiap pertandingan, dari keseluruhan tim melakukan penyerangan, sedangkan dalam kejuaran bola voli nasional seperti Proliga, smash backcourt dilakukan mencapai sekitar 10-14\%, dan dalam kejuaraan dunia smash backcourt bisa mencapai $17-20 \%$. Hal tersebut terjadi karena atlet bola voli senior atau kelas dunia sudah menguasai teknik smash backcourt, sehingga gerakan smash backcourt terjadi secara otomatis, sedangkan atlet yunior belum menguasai teknik smash backcourt, meskipun demikian masih jarang sekali pelatih klub bola voli yang melatih teknik smash backcourt kepada atletnya.

Smash backcourt tidak kalah penting dengan smash yang lainnya, karena pada saatsaat tertentu teknik smash ini merupakan satusatunya teknik yang bisa digunakan untuk mendapatkan poin. Semua pemain harus menguasai teknik smash dengan kecepatan dan ketepatan yang baik, kecuali seoarang set-uper dan libero. Pemain harus dibina dan dilatih secara spesifik dan terarah untuk meguasai teknik smash backcourt, sehingga dapat melakukan teknik smash backcourt dengan sempurna.

Menurut Bompa (2000, p.4) latihan adalah upaya seseorang mempersiapkan dirinya untuk tujuan tertentu, latihan merupakan suatu proses yang disengaja untuk menguasai suatu jenis keterampilan atau meningkatkan kondisi. Sedangkan menurut Morris \& Hale (2006, p.97) practice is essential if learning is to take place. To the congnitivists, practice follows instruction. It is the keyfactor in the intermediate and autonomous stages of fits and posner, would see it as being when we move from declarative knowledge (knowing what to do) to procedural knowledge (developing the ability to perform the task)". Artinya latihan adalah hal yang penting untuk mengembangkan pengetahuan dengan mengikuti instruksi yang diberikan yang akan mengubah pengetahuan deklaratif (mengetahui apa yang harus dilakukan) hingga pengetahuan prosedural (mengembangkan kemampuan untuk melakukan tugas). Sedangkan menurut Birch, Maclaren \& George (2005, p.1) "Exer- cise is defined as repetitive physical activity or move-ment aimed at improving or maintaining fitness or health". Artinya latihan didefinisikan sebagai aktivitas fisik yang berulang yang bertujuan untuk meningkatkan atau mempertahankan kebugaran maupun kesehatan.

Metode-metode latihan smash sangat mempengaruhi keberhasilan dari latihan smash itu sendiri, banyak sekali metode latihan smash yang digunakan oleh seorang pelatih termasuk metode latihan sederhana dan metode latihan kompleks. Menurut Irianto (2002, pp.83-85) metode latihan sederhana yaitu dengan teknik demonstrasi dan meniru, sedangkan metode latihan kompleks yaitu dengan teknik pembentukan gerakan dan perangkaian gerakan. Perbedaan yang mencolok antara metode latihan sederhana dan metode latihan kompleks terdapat pada proses pelaksanaan latihan. Pelaksanaan latihan teknik dengan metode latihan sederhana dilakukan dengan gerakan keseluruhan dari teknik tersebut, sedangkan metode latihan kompleks dilakukan dengan menyederhanakan gerakan yang kompleks menjadi gerak yang sederhana, dan latihan dilakukan bagian demi bagian smash backcourt.

"Keberhasilan latihan teknik smash dipengaruhi berbagai hal, diantaranya kelincahan, keseimbangan, kekuatan, daya tahan, kelentukan kecepatan dan koordinasi" Faruq (2009, p.21). Smash backcourt merupakan teknik yang sangat kompleks apalagi pada saat latihan ditambah dengan teknik yang lainnya seperti passing atas maupun passing bawah, sehingga pada latihan teknik smash backcourt seorang atlet sangat membutuhkan koordinasi yang baik. Hal tersebut didukung dari pendapat Sukadiyanto (2010, p.230) "tanpa memiliki kemampuan koordinasi yang baik, maka atlet akan kesulitan dalam melakukan teknik secara selaras, serasi, dan stimulan, sehingga nampak luwes dan mudah".

Menurut Suharjana (2013, p.147) koordinasi merupakan kemampuan untuk memadukan dua macam gerakan atau lebih ke dalam satu atau lebih pola gerak yang khusus. Sedangkan menurut Planinsec \& Pisot (2006, p.668) "Coordination involves patterns of body or limb movement, which means that we need to use the appropriate limb or body movement coordination patterns in order to be able to perform motor skills". Artinya koordinasi melibatkan pola tubuh atau gerakan anggota badan, yang berarti bahwa manusia perlu menggunakan anggota badan yang sesuai atau 
pola koordinasi gerakan tubuh agar mampu melakukan keterampilan motorik. Menurut Sukadiyanto (2010, p.223) koordinasi merupakan hasil perpaduan kinerja dari kualitas otot, tulang, dan persendian dalam menghasilkan satu gerak yang efektif dan efisien. Jadi koordinasi mata-tangan merupakan kemampuan seseorang dalam mengintegrasikan antara gerakan, mata (pandangan) di mana mata sebagai pemegang fungsi utama dan tangan sebagai fungsi gerak untuk melakukan gerakan sesuai yang diinginkan.

Koordinasi yang baik tentunya akan menentukan atlet dalam mengontrol keselarasan, efektifitas, dan keseimbangan dalam melakukan suatu keterampilan. Atlet yang mempunyai koordinasi rendah akan lebih lama menguasai latihan-latihan, dikarenakan memerlukan adaptasi efisiensi penggunaan waktu, ruang dan energi yang lebih lama di dalam melaksanakan suatu gerakan. Setiap atlet mempunyai tingkat koordinasi yang berbeda. Perbedaan koordinasi yang ada pada setiap atlet harus menjadi pertimbangan sebagai suatu faktor yang menentukan hasil smash, dengan mengetahui perbedaan koordinasi dari setiap atlet maka seorang pelatih harus mengetahui metode latihan yang tepat digunakan.

Ditinjau dari gerakannya, smash merupakan suatu keterampilan yang memiliki gerakan yang kompleks. Smash merupakan gabungan dari beberapa gerakan yang harus dikoordinasi dengan baik dan harmonis. Gerakan smash bila diuraikan terdiri atas awalan, menolak untuk melompat, memukul dan mendarat. Untuk melakukan beberapa unsur gerakan tersebut secara baik dan harmonis diperlukan kemampuan koordinasi gerakan yang baik dan pada saat memukul bola dibutuhkan koordinasi matatangan yang baik. Menurut Suharjana (2013, p.147) dalam permainan bola voli harus memiliki koordinasi yang baik ketika melakukan gerakan smash. Hal ini dikarenakan dalam permainan bola voli dibutuhkan kecermatan pandangan dan keakuratan pukulan, pada khususnya saat melakukan smash. Kecermatan pandangan saat mengantisipasi umpan bola dari tosser dan segera bergerak untuk memukul bola pada titik ketinggian yang tepat, membuat keberadaaan koordinasi mata-tangan sangat dibutuhkan. Kesalahan dalam antisipasi bola dari tosser menjadikan gerakan memukul bola tidak tepat, sehingga pukulan akan menjadi tidak optimal.

\section{METODE}

Metode yang digunakan dalam penelitian ini adalah metode eksperimen. Metode penelitian eksperimen ini menggunakan desain faktorial 2 x 2. Menurut Sudjana (2002, p.148) "Metode eksperimen faktorial adalah eksperimen yang hampir atau semua taraf sebuah faktor dikombinasikan atau disilangkan dengan semua taraf setiap faktor lainnya yang ada dalam eksperimen". Masing-masing faktor terdiri atas dua buah taraf, dengan menggunakan tes awal (pre-test) dan tes akhir (post-test). Data penelitian ini disusun dalam kerangka desain penelitian dengan rancangan faktorial $2 \times 2$ sebagai berikut:

Tabel 1. Kerangka desain penelitian

\begin{tabular}{ccc}
\hline \multirow{2}{*}{$\begin{array}{c}\text { Variabel Manipulatif } \\
\text { Variabel Atributif }\end{array}$} & $\begin{array}{c}\text { Sederhana } \\
\text { (a1) }\end{array}$ & $\begin{array}{c}\text { Kompleks } \\
\text { (a2) }\end{array}$ \\
\hline $\begin{array}{c}\text { Koordinasi Tinggi } \\
\text { (b1) }\end{array}$ & a1b1 & a2b1 \\
\hline $\begin{array}{c}\text { Koordinasi Rendah } \\
\text { (b2) }\end{array}$ & a1b2 & a2b2 \\
\hline
\end{tabular}

Keterangan:

a1b1 :Kelompok atlet bola voli yang mempunyai koordinasi tinggi dilatih dengan metode latihan sederhana.

a1b2 :Kelompok atlet bola voli yang mempunyai koordinasi rendah dilatih dengan metode latihan sederhana.

a2b1 :Kelompok atlet bola voli yang mempunyai koordinasi tinggi dilatih dengan metode latihan kompleks.

a2b2 :Kelompok atlet bola voli yang mempunyai koordinasi rendah dilatih dengan metode latihan kompleks.

\section{Tempat dan Waktu Penelitian}

Pelaksanaan penelitian ini di lapangan bola voli di FIK UNY dan lapangan bola voli di SMK Negeri II Yogyakarta. Penelitian eksperimen ini dilakukan 21 kali pertemuan selama tujuh minggu, dengan frekuensi latihan setiap minggunya 3 kali pertemuan. Penelitian dimulai pada tanggal 10 Maret 2014 sampai dengan tanggal 3 Mei 2014.

\section{Populasi dan Sampel Penelitian}

Menurut Sudjana (2002. p.6) populasi adalah totalitas semua nilai yang mungkin, hasil menghitung ataupun pengukuran kuantitatif kualitatif, mengenai karakteristik tertentu dari semua anggota kumpulan lengkap dan jelas, yang dipelajari sifat-sifatnya. Populasi yang 
digunakan dalam penelitian ini yaitu atlet klub bola voli yunior putra D.I Yogyakarta.

Teknik pengambilan sampel dalam penelitian ini ditentukan dengan teknik purposive sampling. Pengambilan sampel dengan teknik purposive sampling berdasarkan kriteria atau syarat, serta mempunyai tujuan tertentu. Adapun langkah-langkah untuk menentukan sampel adalah sebagai berikut: (1) sampel yang diambil yaitu seluruh atlet yunior putra klub bola voli Yuso Sleman dan klub bola voli Yuso Gunadarma (klub bola voli Yuso Sleman dan Yuso Gunadarma dijadikan sampel karena memiliki berbagai kesamaan karakteristik, yaitu prestasi yang hampir setara, keseragaman umur atlet, keaktifan dalam berlatih, dan keaktifan kepengurusan, (2) kriteria sampel yang diambil adalah atlet yunior putra yang berumur antara 14 tahun sampai dengan 19 tahun, yang bertugas sebagai penyerang/smasher, (3) dari 41 atlet didapat 36 atlet yang memenuhi kriteria untuk dijadikan sampel, selanjutnya dari total 36 atlet dilakukan tes koordinasi mata-tangan, untuk menggolongkan atlet yang memiliki koordinasi tinggi dan rendah, (4) setelah tes koordinasi mata-tangan dilakukan, maka disusun berdasarkan ranking koordinasi, yaitu dari skor tertinggi sampai skor terendah, dan (5) kemudian menentukan persentase skor, yakni: $27 \%$ skor tinggi dan $27 \%$ skor rendah.

Pembagian kelompok sampel 27\% skor tinggi dan 27\% menurut pendapat Suharsimi (2010, p.212) untuk menentukan sampel yaitu membagi dengan mengambil kedua kutubnya saja, yakni: $27 \%$ skor teratas sebagai kelompok koordinasi tinggi dan $27 \%$ skor terbawah sebagai kelompok koordinasi rendah. Hal tersebut dimaksudkan untuk memaksimalkan pengaruh dari latihan yang diberikan, sehingga dengan teknik ini hasil penelitian akan jelas terlihat dari kelompok atlet yang mempunyai koordinasi tinggi dan dari kelompok atlet yang mempunyai koordinasi rendah. Setelah diketahui tingkat koordinasi semua atlet, selanjutnya diperingkat dari atlet yang mempunyai koordinasi tertinggi sampai atlet yang memiliki koordinasi terendah, setelah data tingkat koordinasi urut dari yang tertinggi sampai terendah, sampel untuk kelompok koordinasi tinggi diambil dengan $27 \%$ x 36 : 9,72 dibulatkan menjadi 10, sedangkan sampel untuk kelompok koordinasi rendah yaitu $27 \% \mathrm{x}$ $36: 9,72$ dibulatkan menjadi 10 , dengan begitu terdapat dua kelompok yaitu 10 atlet dengan koordinasi tinggi dan 10 atlet dengan koordinasi rendah, sedangkan kelompok atlet yang mempunyai koordinasi sedang tidak dijadikan sebagai sampel penelitian.

Total sampel dalam penelitian yaitu 20 atlet, dengan rincian 10 atlet berkoordinasi tinggi dan 10 atlet berkoordinasi rendah. Langkah selanjutnya yaitu membagi atlet yang memiliki koordinasi tinggi menjadi dua kelompok dengan cara diundi (random), begitupun dengan atlet yang memiliki koordinasi rendah, sehingga didapat empat kelompok dengan rincian dua kelompok dengan koordinasi tinggi dan dua kelompok dengan koordinasi rendah, dan setiap kelompok terdiri atas 5 atlet. Pembagian kelompok dengan cara ini akan lebih objektif bagi semua subjek penelitian. Hal ini didasarkan atas kesempatan yang sama bagi semua objek untuk masuk ke dalam setiap kelompok. Pembagian metode latihan dilakukan dengan undian (random), dari hasil undian didapat metode latihan sederhana dilakukan di klub bola voli Yuso Sleman sedangkan metode latihan kompleks dilakukan di klub bola voli Yuso Gunadarma.

\section{Variabel Penelitian}

Variabel bebas (Independent) Variabel bebas manipulatif yaitu metode latihan yang terdiri atas dua metode, antara lain: (1) metode latihan sederhana, dan (2) metode latihan kompleks. Variabel bebas atributif (yang dikendalikan) dalam penelitian ini, terdiri: (1) koordinasi tinggi, dan (2) koordinasi rendah. Variabel terikat dalam penelitian ini yaitu hasil smash backcourt.

\section{Teknik dan Instrumen Pengumpulan Data}

Menurut Sugiyono (2012, p.148) "Instrumen adalah alat ukur yang digunakan dalam penelitian". Instrumen yang digunakan untuk memperoleh data koordinasi dilakukan dengan menggunakan tes koordinasi mata-tangan. Untuk mengukur tingkat koordinasi mata-tangan menggunakan tes lempar tangkap bola tenis, sedangkan tes ketepatan smash backcourt yang digunakan adalah modifikasi dari tes smash Laveage. Tes ini bertujuan untuk mengukur ketepatan teknik smash backcourt, dalam kaitannya terhadap ketepatan mengarahkan bola dan ketepatan smash dengan bola keras kesasaran tertentu.

\section{Validitas dan Reliabilitas Instrumen}

Validitas adalah sejauh mana ketepatan dan kecermatan suatu alat ukur dalam melakukan fungsi ukurannya atau memberikan hasil 
ukur yang sesuai dengan maksud dilakukannya pengukuran tersebut. Menurut Muhidin (2007, p.30) instrumen dinyatakan memiliki validitas apabila instrumen tersebut telah dirancang dengan baik dan mengikuti teori dan ketentuan yang ada. Validitas hasil smash backcourt sebesar 0,895 dan validitas untuk koordinasi matatangan sebesar 0,820 . Reliabilitas untuk ketepatan smash backcourt sebesar 0,904 dan koordinasi sebesar 0,897.

\section{Teknik Analisis Data}

Teknik analisis data yang digunakan dalam penelitian ini dengan menggunakan SPSS 20 yaitu Analisis Varian (ANAVA) dua jalur pada taraf signifikansi $\alpha=0,05$. Untuk memenuhi asumsi ANAVA maka dilakukan uji normalitas dengan Kolmogorov Smirnow dan homogenitas dengan uji Levene Test. Selanjutnya dilakukan uji lanjutan yaitu uji Pairwise comparisons.

\section{HASIL DAN PEMBAHASAN}

Hasil yang diperoleh dari penelitian berupa data yang merupakan gambaran umum tentang masing-masing variabel yang terkait dalam penelitian. Melalui gambaran umum tersebut tampak kondisi awal dan kondisi akhir dari setiap variabel yang diteliti dengan melakukan pengolahan data setelah data berhasil dikumpulkan selama periode latihan yang telah ditentukan.

Pada Tabel 2 diperoleh data sebagai berikut: (1) untuk kelompok A1B1 pada tes awal diperoleh rata-rata sebesar 20.6 setelah dilakukan perlakuan dengan metode latihan sederhana didapat rata-rata meningkat menjadi 25.2 sehingga peningkatan pada kelompok A1B1 sebesar 4.6, (2) untuk kelompok A2B1 pada tes awal diperoleh rata-rata sebesar 23 setelah dilakukan perlakuan metode latihan kompleks didapat rata-rata meningkat menjadi 33.8 sehingga peningkatan pada kelompok A2B1 sebesar 10.8, (3) untuk kelompok A1B2 pada tes awal diperoleh rata-rata sebesar 18.4 setelah dilakukan perlakuan dengan metode latihan sederhana didapat rata-rata meningkat menjadi 26 sehingga peningkatan pada kelompok A1B2 sebesar 7.6, (4) untuk kelompok A2B2 pada tes awal diperoleh rata-rata sebesar 18 setelah dilakukan perlakuan dengan metode latihan kompleks didapat rata-rata meningkat menjadi 22.4 sehingga peningkatan pada kelompok A2B2 sebesar 4.4.
Dari perbandingan peningkatan rerata setiap kelompok tersebut dapat disimpulkan bahwa urutan peningkatan dari yang terbesar adalah (1) pada kelompok metode latihan kompleks dengan koordinasi tinggi (A2B1), (2) pada kelompok metode latihan sederhana dengan koordinasi rendah (A1B2), (3) pada kelompok metode latihan sederhana dengan koordinasi tinggi (A1B1), dan (4) pada kelompok metode latihan kompleks dengan koordinasi rendah (A2B2).

\section{Uji Normalitas Data}

Uji normalitas data dalam penelitian ini digunakan program software SPSS version 20.0 for windows dengan taraf signifikansi 5\% atau 0,05 dengan Kolmogorov Smirnov. Hasil uji normalitas data yang dilakukan pada tes awal (pree-test) hasil smash backcourt, didapat dari hasil uji normalitas data yang dilakukan pada metode latihan sederhana yang mempunyai koordinasi tinggi (A1B1) terdapat tingkat signifikan sebesar 0,941 ini berarti $p>0,05$, artinya data tersebut berdistribusi normal. Pada metode latihan kompleks yang mempunyai koordinasi tinggi (A2B1) terdapat tingkat signifikan sebesar 0,99 ini berarti $\mathrm{p}>0,05$, artinya data tersebut berdistribusi normal. Pada metode latihan sederhana yang mempunyai koordinasi rendah (A1B2) terdapat tingkat signifikan sebesar 0,759 , ini berarti $p>0,05$, artinya data tersebut berdistribusi normal. Selanjutnya pada metode latihan kompleks yang mempunyai koordinasi rendah (A2B2) terdapat tingkat signifikan sebesar 0,892 ini berarti $p>0,05$, artinya data tersebut berdistribusi normal. Hal ini berarti data pada tes setiap kelompok merupakan statistik parametrik.

\section{Uji Homogenitas}

Uji homogenitas dilakukan untuk menguji persamaan beberapa sampel yaitu homogen atau tidak. Uji homogenitas dimaksudkan menguji kesamaan varian antara kelompok 1 dan kelompok 2. Uji homogenitas pada penelitian ini adalah uji Levene Test. Berdasarkan analisis statistik uji homogenitas yang dilakukan, diperoleh nilai signifikansi sebesar 0,406>0,05. Hal ini berarti dalam kelompok data memiliki varian yang homogen. Hal ini berarti data pada tes setiap kelompok merupakan statistik parametrik. 
Jurnal Keolahragaan 4 (2), September 2016 - 128

Agung Kristiawan, Sukadiyanto

Tabel 2. Deskripsi data hasil smash backcourt.

\begin{tabular}{cccrrr}
\hline $\begin{array}{c}\text { Tingkat } \\
\text { koordinasi }\end{array}$ & Metode latihan & Statistik & Hasil tes awal & Hasil tes akhir & Penigkatan \\
\hline Tinggi & Sederhana A1B1 & Jumlah & 103 & 126 & 23 \\
& & Rerata & 20.6 & 25.2 & $\mathbf{4 . 6}$ \\
& SD & 1.14 & 1.48 & 0.54 \\
& Kompleks A2B1 & Jumlah & 115 & 169 & 54 \\
& & Rerata & 23 & 33.8 & $\mathbf{1 0 . 8}$ \\
& & 1.87 & 2.00 & 2.88 \\
Rendah & SD & 92 & 130 & 38 \\
& \multirow{4}{*}{ Kederhana A1B2 } & Jumlah & 18.4 & 26 & $\mathbf{7 . 6}$ \\
& Rerata & 2.30 & 3.03 & 1.30 \\
& SD & 90 & 112 & 22 \\
& & & 18 & 22.4 & $\mathbf{4 . 4}$ \\
& & Jumlah & 2.45 & 2.88 & 1.14 \\
\hline & Rerata & & & \\
\hline
\end{tabular}

\section{Pengujian Hipotesis}

Pengujian hipotesis dilakukan berdasar hasil analisis data dan interpretasi analisis varian dua jalur. Analisis varian dua jalur digunakan untuk menguji pengaruh utama antara variabel bebas metode latihan dan variabel atribut koordinasi terhadap hasil smash backcourt. Uji Pairwise Comparisons ditempuh sebagai langkah uji rata-rata setelah ANAVA guna mengetahui secara terperinci rata-rata beda.

\section{Hipotesis I}

Hipotesis yang dinyatakan bahwa ada perbedaan pengaruh antara metode latihan sederhana dan metode latihan kompleks terhadap hasil smash backcourt bagi atlet yunior putra klub bola voli Yuso Sleman dan Yuso Gunadarma. Berdasarkan dari nilai signifikansi Univariate tests sebesar $0,035<0,05$ berarti bahwa lebih kecil dari taraf signifikan, dengan demikian hipotesis yang menyatakan ada perbedaan pengaruh antara metode latihan sederhana dan metode latihan kompleks terhadap hasil smash backcourt diterima.

Dari analisis lanjutan diperoleh bahwa metode latihan kompleks mempunyai peningkatan yang lebih baik daripada metode latihan sederhana. Rata-rata peningkatan metode latihan kompleks sebesar 28,1 dan rata-rata peningkatan metode latihan sederhana sebesar 25.6. Jadi dengan lebih besar rata-rata peningkatan metode latihan kompleks, maka metode latihan kompleks memberikan hasil ketepatan smash backcourt yang lebih baik daripada metode latihan sederhana.

\section{Hipotesis II}

Hipotesis yang dinyatakan bahwa ada perbedaan hasil smash backcourt antara atlet yang mempunyai koordinasi tinggi dan koordinasi rendah bagi atlet yunior putra klub bola voli Yuso Sleman dan Yuso Gunadarma. Berdasarkan dari nilai signifikansi Univariate Tests sebesar $0,000<0,05$ yang berarti bahwa lebih kecil dari taraf signifikan, dengan demikian hipotesis yang menyatakan ada perbedaan hasil ketepatan smash backcourt antara atlet yang mempunyai koordinasi tinggi dan atlet yang mempunyai koordinasi rendah, diterima.

Dari analisis lanjutan diperoleh bahwa ternyata atlet yang mempunyai koordinasi tinggi mempunyai peningkatan yang lebih baik daripada atlet yang mempunyai koordinasi rendah, rata-rata peningkatan masing-masing yaitu atlet yang mempunyai koordinasi tinggi sebesar 29.5 dan atlet yang mempunyai koordinasi rendah sebesar 24.2. Perbedaan rata-rata dari peningkatan smash backcourt menunjukkan bahwa atlet yang mempunyai koordinasi tinggi mempunyai hasil ketepatan smash backcourt yang lebih baik daripada atlet yang mempunyai koordinasi rendah.

\section{Hipotesis III}

Hipotesis yang dinyatakan bahwa ada interaksi antara metode latihan dan koordinasi terhadap hasil smash backcourt bagi atlet yunior putra klub bola voli Yuso Sleman dan Yuso Gunadarma. Berdasarkan hasil perhitungan Tests of Between-Subjects Effects, didapat bahwa taraf signifikansi sebesar $0,000<0,05$, hal ini menunjukkan bahwa tingkat signifikan 5\% ada pengaruh bersama antara metode latihan dan koordinasi terhadap hasil smash 
backcourt. Dengan demikian hipotesis yang dinyatakan bahwa ada interaksi antara metode latihan dan koordinasi terhadap hasil smash backcourt bagi atlet yunior putra, diterima.

Setelah teruji terdapat interaksi antara metode latihan dan koordinasi terhadap hasil smash backcourt, maka dilakukan uji lanjut dengan menggunakan Pairwise comparisons. Dari hasil uji lanjut Pairwise comparisons didapat kelompok yang terdapat perbedaan secara signifikan: (a) metode latihan sederhana dengan tingkat koordinasi tinggi dipasangkan dengan metode latihan kompleks dengan tingkat koordinasi tinggi terdapat perbedaan pengaruh yang signifikan. Atlet yang dilatih dengan metode latihan kompleks dengan tingkat koordinasi tinggi memberikan hasil smash backcourt yang lebih baik (A1B1 dengan A2B1), (b) Metode latihan sederhana dengan koordinasi rendah dipasangkan dengan metode latihan kompleks dengan koordinasi tinggi terdapat perbedaan pengaruh yang signifikan. Atlet yang dilatih dengan metode latihan kompleks dengan tingkat koordinasi tinggi memberikan hasil smash backcourt yang lebih baik (A1B2 dengan A2B1), (c) metode latihan sederhana dengan koordinasi rendah dipasangkan dengan metode latihan kompleks dengan koordinasi rendah terdapat perbedaan pengaruh yang signifikan. Atlet yang dilatih dengan metode latihan sederhana dengan tingkat koordinasi rendah memberikan hasil smash backcourt yang lebih baik (A1B2 dengan A2B2), (d) metode latihan kompleks dengan tingkat koordinasi tinggi dipasangkan dengan metode latihan kompleks dengan tingkat koordinasi rendah terdapat perbedaan pengaruh yang signifikan. Atlet yang dilatih dengan metode latihan kompleks dengan tingkat koordinasi tinggi memberikan hasil smash backcourt yang lebih baik (A2B1 dengan A2B2).

Sedangkan pasangan-pasangan lainnya dinyatakan tidak mempunyai perbedaan pengaruh yang signifikan, pasangan tersebut yaitu: (a) metode latihan sederhana dengan koordinasi tinggi dipasangkan dengan metode latihan sederhana dengan koordinasi rendah tidak terdapat perbedaan pengaruh yang signifikan (A1B1 dengan A1B2), (b) metode latihan sederhana dengan koordinasi rendah dipasangkan dengan metode latihan kompleks dengan koordinasi rendah tidak terdapat perbedaan pengaruh yang signifikan (A1B1 dengan A2B2).

Pembahasan hasil penelitian ini memberikan penafsiran yang lebih lanjut mengenai hasil-hasil analisis data yang telah dikemukakan. Berdasarkan pengujian hipotesis menghasilkan dua kelompok kesimpulan analisis yaitu: (1) ada perbedaan pengaruh yang bermakna antara faktor-faktor utama penelitian. (2) ada interaksi yang bermakna antara faktor-faktor utama dalam bentuk interaksi dua faktor. Kelompok kesimpulan analisis tersebut dapat dipaparkan lebih lanjut sebagai berikut:

\section{Perbedaan Pengaruh Antara Metode Latih- an Sederhana dan Metode Latihan Kom- pleks terhadap Hasil Smash Backcourt}

Berdasarkan pengujian hipotesis pertama yang menyatakan bahwa ada perbedaan pengaruh yang signifikan antara kelompok atlet bola voli yang dilatih menggunakan metode latihan sederhana dan metode latihan kompleks, dapat diterima. Pada kelompok atlet bola voli yang dilatih dengan metode latihan kompleks mempunyai peningkatan hasil smash backcourt lebih baik jika dibandingkan dengan atlet bola voli yang dilatih menggunakan metode latihan sederhana. Hal tersebut membuktikan bahwa metode latihan sederhana dan metode latihan kompleks mempunyai perbedaan pengaruh yang signifikan terhadap hasil smash backcourt.

Metode latihan sederhana dan metode latihan kompleks mempunyai berbagai perbedaan dalam proses latihan yang dilakukan. Inti dari perbedaan antara metode latihan sederhana dan metode latihan kompleks yaitu metode latihan sederhana dilakukan secara keseluruhan dari teknik yang dilatih, dengan meniru, mempratekkan, dan pengkoreksian gerakan yang salah, sedangkan metode latihan kompleks lebih menekankan pada pembentukan gerakan dan latihan gerak yang disederhanakan, yaitu bagian-bagian dari teknik tersebut dan selanjutnya dirangkaikan. Menurut Irianto (2002, pp.83-85) metode latihan sederhana yaitu meniru, demonstrasi, mencoba gerakan, dan mempraktekkan, sedangkan metode latihan kompleks yaitu pembentukan gerakan, penyederhanaan gerakan, dan perangkaian.

Dalam metode latihan kompleks setelah atlet memahami gerakan sederhana yang merupakan bagian dari gerak kompleks dan memahami hubungan antar gerak, maka langkah selanjutnya yaitu merangkaikan satu demi satu gerak-gerak sederhana tersebut menjadi gerak yang kompleks. Proses latihan yang dilakukan yaitu dengan latihan dari bagian demi bagian, metode latihan yang dilakukan secara per bagian merupakan metode latihan bagian (part 
method), jadi didalam metode latihan kompleks dilakukan metode bagian. Menurut Harsono (2005, p.54) metode bagian tepat digunakan untuk latihan teknik yang rumit, tetapi proses perangkaian bagian demi bagian membutuhkan penguasaan gerakan setiap bagian dengan baik.

Metode latihan kompleks menyederhanakan gerak yang kompleks menjadi gerak sederhana, dalam hal ini gerak sederhana pada metode latihan kompleks yang dimaksud yaitu gerak untuk passing, gerak bersiap melakukan smash, gerak awalan smash, gerak loncatan smash, gerak saat melakukan smash dan gerak saat pendaratan. Bagian-bagian gerak tersebut dipelajari secara mendalam dan dipraktekkan, setelah atlet memahami benar akan semua bagian gerak tersebut maka dilakukan perangkaian dari berbagai gerak menjadi satu keutuhan gerak smash backcourt. Hal tersebut berbeda dengan konsep metode latihan sederhana yang menekankan pada latihan gerak secara menyeluruh dari teknik tersebut dan pada koreksi gerakan. Latihan teknik yang dilakukan secara menyeluruh seperti halnya dengan metode latihan keseluruhan (whole method). Menurut Martens (2004, p.202) "when the task is low in complexity and high interdependence, have your athletes practice the whole technique". Menurut pendapat Martens tersebut bahwa teknik yang rendah kompleksitasnya dan tinggi ketergantungan-nya maka seharusnya metode keseluruhan digunakan untuk berlatih. Jadi metode latihan sederhana tepat digunakan untuk latihan teknik yang tidak tinggi tingkat kompleksitasnya. Berdasarkan kelebihan masingmasing metode latihan tersebut terlihat perbedaan konsep pemberian latihan teknik smash backcourt.

Hasil metode latihan terhadap subjek atlet yang dilatih sangatlah penting dipertimbangkan, dalam hal ini subjek penelitiannya adalah atlet bola voli yunior putra yang belum menguasai teknik smash backcourt dan proses latihan smash backcourt masih jarang dilakukan oleh pelatih, sehingga ditinjau dari berbagai teori yang ada, metode latihan kompleks lebih tepat digunakan untuk melatih atlet pemula yaitu atlet bola voli yunior. Metode latihan kompleks dapat dilihat dari proses latihan yang dilakukan, yaitu pembentukan gerakan, penyederhanaan gerakan, perangkaian dari bagianbagian gerak yang sederhana menjadi satu gerakan untuh, selain itu pada metode latihan kompleks atlet lebih mengetahui hubungan satu gerak dengan gerak yang lain dan lebih bisa mendalami gerak yang benar dari bagian per bagian gerak smash backcourt. Menurut Martens (2004, p.202) "part practice is better when the task is high in complexity and low in interdependence". Makna dari pendapat Martens tersebut yaitu latihan per bagian gerak lebih baik ketika tugas (gerak) yang mempunyai kompleksitas tinggi dan rendah ketergantungan.

Berdasarkan pembahasan tersebut, terlihat bahwa metode latihan kompleks lebih tepat digunakan untuk atlet pemula. Kebenaran teori tersebut diperkuat dengan hasil analisis data, dalam penelitian ini metode latihan kompleks mempunyai peningkatan rata-rata sebesar 28.1, dan rata-rata peningkatan metode latihan sederhana sebesar 25.6. Peningkatan rata-rata metode latihan kompleks lebih besar, maka dapat disimpulkan bahwa metode latihan kompleks memberikan pengaruh pada peningkatan hasil smash backcourt lebih baik daripada metode latihan sederhana.

\section{Perbedaan Pengaruh Antara Koordinasi Tinggi dan Rendah terhadap Hasil Smash Backcourt}

Berdasarkan pengujian hipotesis kedua yang menyataan bahwa atlet yang mempunyai koordinasi tinggi lebih baik dibandingkan dengan atlet yang mempunyai koordinasi rendah dalam hubungannya terhadap hasil smash backcourt atlet bola voli yunior putra, dapat diterima. Hal tersebut membuktikan bahwa koordinasi tinggi dan koordinasi rendah mempunyai perbedaan pengaruh yang signifikan terhadap hasil smash backcourt. Jadi dapat disimpulkan bahwa tinggi rendahnya koordinasi seorang atlet mempengaruhi baik buruknya hasil smash backcourt, dalam hal ini koordinasi tinggi memberikan peningkatan yang lebih baik.

Koordinasi merupakan kemampuan untuk memadukan berbagai macam gerakan ke dalam satu atau lebih pola gerak khusus. Sesuai dengan pendapat yang dikemukakan Sukadiyanto (2010, p.221) olahragawan yang tidak memiliki kemampuan koordinasi yang baik, maka akan kesulitan dalam melakukan teknik secara selaras, serasi, dan simultan, sehingga nampak luwes dan mudah. Dengan demikian atlet yang mempunyai koordinasi yang baik lebih cepat dan efisien dalam bergerak serta gerak tersebut selaras, serasi, dan stimulan, sehingga terlihat luwes dan mudah. Hal yang sama dikemukakan oleh Suharjana (2013, p.147) atlet yang memiliki koordinasi 
yang baik, akan mampu menampilkan keterampilan dengan sempurna dan dapat dengan cepat mengatasi permasalahan tugas (gerak) selama latihan yang muncul secara tidak terduga, contoh gerak yang yang memerlukan koordinasi yang baik yaitu pemain bola voli ketika melakukan smash. Smash merupakan gerakan yang paling kompleks dalam olahraga bola voli, sehingga teknik ini sangat membutuhkan koordinasi yang baik bagi setiap atlet bola voli yang melakukan smash. Bompa (2000, p.43) mengemukakan "A well-coordinated child will always acquire a skill quickly and be able to perform it smoothly. Compared with a child who might perform a movement with stiffness and difficulty, a well-coordinated young athlete will spend less energy for the same performance. Therefore, good coordination results in more skill effectiveness". Artinya anak yang mempunyai koordinasi baik akan selalu mendapatkan sebuah keahlian dengan cepat dan dapat melakukan keterampilan tersebut dengan sangat lembut, dibandingkan dengan anak yang mungkin melakukan gerakan dengan kekakuan dan kesulitan, seorang atlet muda yang mempunyai koordinasi baik akan menghabiskan energi yang lebih sedikit untuk penampilan yang sama, oleh karena itu koordinasi yang baik akan lebih efektif dalam suatu penampilan. Dalam suatu proses latihan, koordinasi yang dimiliki setiap atlet mempengaruhi peningkatan hasil dari latihan tersebut. Dalam setiap tim bolavoli pasti mempunyai atlet dengan koordinasi yang berbeda-beda, dengan perbedaan tingkat koordinasi atlet tersebut maka akan mempengaruhi hasil dari latihan, oleh sebab itu peningkatan koordinasi atlet dapat dilakukan dengan berbagai keterampilan seperti melakukan gerakan anggota badan yang tidak biasa dipakai, seperti lempar tangkap bola dengan tangan kiri, atau bisa dilakukan dengan melakukan arah gerak yang jarang dilakukan, seperti berjalan mundur dan berjalan ke samping. Selain contoh tersebut masih banyak latihan-latihan yang dapat digunakan untuk meningkatkan koordinasi seorang atlet.

Atlet yang mempunyai koordinasi rendah tentunya akan menghambat dalam proses latihan, karena atlet tersebut akan kesulitan memadukan berbagai macam gerakan ke dalam satu atau lebih pola gerak khusus. Tingginya koordinasi seorang atlet sangat diperlukan dalam proses latihan suatu teknik tertentu, sehingga tingginya koordinasi memberikan dampak yang positif pada proses belajar gerak. Berdasarkan pembahasan tersebut menunjukan bahwa atlet yang mempunyai koordinasi tinggi mengalami peningkatan hasil smash backcourt yang lebih baik daripada atlet yang mempunyai koordinasi rendah. Hal tersebut juga diperkuat dengan hasil analisis data yang menunjukan bahwa perbandingan rata-rata peningkatan hasil smash backcourt, pada atlet yang mempunyai koordinasi tinggi dengan hasil peningkatan yang lebih tinggi dibandingkan dengan atlet yang mempunyai koordinasi rendah. Hasil dari analisis data terlihat bahwa atlet yang mempunyai koordinasi tinggi rata-rata peningkatan sebesar 29.5, sedangkan bagi atlet yang mempunyai koordinasi rendah rata-rata peningkatannya sebesar 24.2. Jadi dengan lebih besarnya ratarata peningkatan pada atlet yang mempunyai koordinasi tinggi, dapat disimpulkan bahwa atlet yang mempunyai koordinasi tinggi lebih baik daripada atlet yang mempunyai koordinasi rendah pada peningkatan hasil smash backcourt atlet bola voli.

\section{Terdapat Interaksi Antara Metode Latihan Sederhana dan Metode Latihan Kompleks Serta Koordinasi Tinggi dan Rendah terha- dap Hasil Smash Backcourt}

Berdasarkan pengujian hipotesis yang ketiga yang menyatakan bahwa terdapat interaksi yang berarti antara metode latihan (metode latihan kompleks dan metode latihan sederhana) dan koordinasi (koordinasi tinggi dan koordinasi rendah) terhadap hasil smash backcourt bagi atlet klub bola voli yunior putra D.I Yogyakarta, dapat diterima.

Berdasarkan hasil penelitian yang dicapai pasangan kelompok yang mempunyai interaksi atau pasangan yang mempunyai perbedaan pengaruh secara signifikan yaitu: (1) metode latihan sederhana dengan tingkat koordinasi tinggi dipasangkan dengan metode latihan kompleks dengan tingkat koordinasi tinggi terdapat perbedaan pengaruh yang signifikan. Atlet yang dilatih dengan metode latihan kompleks dengan tingkat koordinasi tinggi memberikan hasil smash backcourt yang lebih baik, (2) metode latihan sederhana dengan tingkat koordinasi rendah dipasangkan dengan metode latihan kompleks dengan tingkat koordinasi tinggi terdapat perbedaan pengaruh yang signifikan. Atlet yang dilatih dengan metode latihan kompleks dengan tingkat koordinasi tinggi memberikan hasil smash backcourt yang lebih baik, (3) metode latihan sederhana dengan koordinasi rendah dipasangkan dengan metode 
latihan kompleks dengan koordinasi rendah terdapat perbedaan pengaruh yang signifikan. Atlet yang dilatih dengan metode latihan sederhana dengan tingkat koordinasi rendah memberikan hasil smash backcourt yang lebih baik, (4) metode latihan kompleks dengan tingkat koordinasi tinggi dipasangkan dengan metode latihan kompleks dengan tingkat koordinasi rendah terdapat perbedaan pengaruh yang signifikan. Atlet yang dilatih dengan metode latihan kompleks dengan tingkat koordinasi tinggi memberikan hasil smash backcourt yang lebih baik.

Sedangkan pasangan yang tidak mempunyai perbedaan pengaruh secara signifikan yaitu: (1) metode latihan sederhana dengan tingkat koordinasi tinggi dipasangkan dengan metode latihan sederhana dengan tingkat koordinasi rendah tidak terdapat perbedaan pengaruh yang signifikan, (2) metode latihan sederhana dengan tingkat koordinasi rendah dipasangkan dengan metode latihan kompleks dengan tingkat koordinasi rendah tidak terdapat perbedaan pengaruh yang signifikan.

Interaksi pada tiap-tiap kelompok menunjukkan bahwa ada tidaknya pengaruh yang signifikan terhadap peningkatan hasil smash backcourt. Perbedaan pengaruh didapat dari perbedaan metode yang digunakan dan perbedaan tingkat koordinasi atlet. Seperti pendapat Martens yang telah diuraikan di atas bahwa metode latihan kompleks lebih baik digunakan untuk melatih teknik yang mempunyai tingkat kompleksitas tinggi, dan mengenai koordinasi, menurut Bompa (1999, p.380) "coordination is a complex biomotor ability", koordinasi adalah kecakapan dalam melakukan gerak yang kompleks. Berdasarkan teori tersebut dapat disimpulkan bahwa metode latihan kompleks lebih tepat digunakan untuk melatih teknik yang kompleks, dalam hal ini teknik smash backcourt, dan atlet yang memiliki tingkat koordinasi tinggi mampu melakukan gerak kompleks lebih baik daripada atlet yang memiliki tingkat koordinasi rendah, sehingga peningkatan hasil smash backcourt kelompok atlet yang memiliki tingkat koordinasi tinggi lebih baik daripada kelompok atlet yang memiliki tingkat koordinasi rendah.

Menurut hasil penelitian peningkatan rata-rata hasil smash backcourt pada setiap kelompok dapat diurutkan sebagai berikut: (1) kelompok atlet yang mempunyai tingkat koordinasi tinggi dilatih dengan metode latihan kompleks mengalami peningkatan yang paling besar yaitu dengan rata-rata peningkatan sebesar 10,8, (2) kelompok atlet yang mempunyai tingkat koordinasi rendah dilatih dengan metode latihan sederhana yaitu dengan rata-rata peningkatan sebesar 7,6, (3) kelomok atlet yang mempunyai tingkat koordinasi tinggi dilatih dengan metode sederhana yaitu dengan rata-rata peningkatan sebesar 4,6, dan (4) kelompok atlet yang mempunyai tingkat koordinasi rendah dilatih dengan metode latihan kompleks yaitu dengan rata-rata peningkatan sebesar 4,4.

Kelompok atlet yang mempunyai tingkat koordinasi tinggi dilatih dengan metode latihan kompleks merupakan kelompok yang mengalami peningkatan paling besar daripada kelompok yang lainnya, hal ini terjadi pada atlet pemula yang mempunyai koordinasi tinggi akan dapat dengan mudah memahami dan melakukan gerakan yang terdiri atas gerak bagian demi bagian yang dirangkaikan. Jadi dapat disimpulkan bahwa atlet pemula yang mempunyai koordinasi tinggi lebih tepat dilatih dengan menggunakan metode latihan kompleks. Kelompok atlet yang mempunyai koordinasi rendah dilatih dengan metode latihan kompleks merupakan kelompok yang mengalami peningkatan paling rendah, hal ini terjadi pada atlet pemula yang mempunyai koordinasi rendah kesulitan dalam merangkaikan gerak bagian demi bagian menjadi satu keutuhan teknik smash backcourt

\section{SIMPULAN}

Terdapat perbedaan pengaruh yang signifikan antara metode latihan sederhana dan metode latihan kompleks terhadap hasil smash backcourt bagi atlet klub bola voli yunior putra D.I Yogyakarta. Metode latihan kompleks memberikan hasil smash backcourt lebih baik daripada metode latihan sederhana.

Terdapat perbedaan pengaruh yang signifikan antara atlet yang memiliki koordinasi tinggi dan koordinasi rendah terhadap hasil smash backcourt pada klub bola voli yunior putra D.I Yogyakarta. Atlet yang memiliki koordinasi tinggi menghasilkan hasil smash backcourt lebih baik daripada atlet yang memiliki koordinasi rendah.

Terdapat interaksi antara metode latihan dan koordinasi terhadap hasil smash backcourt bagi atlet klub bola voli yunior putra D.I Yogyakarta. Pasangan yang memiliki interaksi atau pasangan yang berbeda secara signifikan yaitu: pertama: Metode latihan sederhana dengan tingkat koordinasi tinggi dipasangkan dengan metode latihan kompleks dengan 
tingkat koordinasi tinggi terdapat perbedaan pengaruh yang signifikan. Atlet yang dilatih dengan metode latihan kompleks dengan tingkat koordinasi tinggi memberikan hasil smash backcourt yang lebih baik. Kedua: metode latihan sederhana dengan koordinasi rendah dipasangkan dengan metode latihan kompleks dengan koordinasi tinggi terdapat perbedaan pengaruh yang signifikan. Atlet yang dilatih dengan metode latihan kompleks dengan tingkat koordinasi tinggi memberikan hasil smash backcourt yang lebih baik. Ketiga: metode latihan sederhana dengan koordinasi rendah dipasangkan dengan metode latihan kompleks dengan koordinasi rendah terdapat perbedaan pengaruh yang signifikan. Atlet yang dilatih dengan metode latihan sederhana dengan tingkat koordinasi rendah memberikan hasil smash backcourt yang lebih baik. Keempat: metode latihan kompleks dengan tingkat koordinasi tinggi dipasangkan dengan metode latihan kompleks dengan tingkat koordinasi rendah terdapat perbedaan pengaruh yang signifikan. Atlet yang dilatih dengan metode latihan kompleks dengan tingkat koordinasi tinggi memberikan hasil smash backcourt yang lebih baik.

Sedangkan pasangan yang tidak mempunyai perbedaan pengaruh secara signifikan yaitu metode latihan sederhana dengan koordinasi tinggi dipasangkan dengan metode latihan sederhana dengan koordinasi rendah tidak terdapat perbedaan pengaruh yang signifikan, dan metode latihan sederhana dengan koordinasi rendah dipasangkan dengan metode latihan kompleks dengan koordinasi rendah tidak terdapat perbedaan pengaruh yang signifikan.

\section{DAFTAR PUSTAKA}

Arikunto, S. (2010). Manajemen penelitian. Jakarta: Rineka Cipta.

Birch, K., Maclaren, D., \& George, K. (2005). Sport \& exercise physiology. New York: Garland Science/BIOS Scientific Publishers.

Bompa, T.O. (1999). Theory and metodology of training. Iowa: Kendall Hunt Publishing Company.

Bompa, T.O. (2000). Total training for young champions. Champaign: Human Kinetics.

Dewan dan Bidang Perwasitan PP. PBVSI. (2004). Peraturan permainan bola voli. Jakarta: PP. PBVSI.
Farug, M.M. (2009). Meningkatkan kebugaran jasmani melalui permainan dan olahraga bolavoli. Surabaya: PT Gramedia Widiasarana.

Harsono., dkk. (2005). Manusia dan olahraga. Bandung: ITB.

Irianto, D. P. (2002). Dasar kepelatihan. Yogyakarta: UNY Press.

Ismaryati. (2006). Tes dan pengukuran olahraga. Surakarta: UPT UNS Press.

Ma'mun, A., \& Subroto, Y.M. (2000). Perkembangan gerak dan belajar gerak. Jakarta: Depdikbud.

Marques, MC, van den Tillaar, R., Gabbett, TJ, Reis, VM, González-Badillo, JJ. (2009). Physical fitness qualities of professional volleyball players: determination of positional differences. $J$ Strength Cond Res.23(4):1106-11. doi: 10.1519/JSC.0b013e31819b78c4.

Martens, R. (2004). Sussessful coaching. 3th edition. American Sport Education Program Founder. Champaign: Human Kinetics.

Morris, T. M., \& Hale, T. (2006). Coaching science theory into practice. Chicester: John Willey \& Sons Ltd.

Muhidin, A. (2007). Analisis regresi, dan jalur dalam penelitian. Bandung: $\mathrm{CV}$ Pestaka Setia.

Planinsec, J., \& Pisot, R. (2006). Motor coordinationan dintelligence level inadolescents. Adolescence, 41(164), 667-76. Retrived from proquest: http://search.proquest.com/docview/195 944737.

Sudjana. (2002). Metoda statistika. Bandung: Penerbit Tasito.

Sugiyono. (2012). Metode penelitian kuantitatif, kualitatif dan $R \quad \& \quad D$. Bandung: Alfabeta.

Suharjana. (2013). Kebugaran jasmani. Yogyakarta: Jogja Global Media.

Sukadiyanto. (2010). Pengantar teori dan metodologi melatih fisik. Yogyakarta: Fakultas Ilmu KeolahragaanUniversitas Negeri Yogyakarta. 
Jurnal Keolahragaan 4 (2), September 2016 - 134

Agung Kristiawan, Sukadiyanto

Chen, Y.C., \& Huang, C.F. (2008). Kinematical analysis of female volleyball spike. 26 International

Conference
Biomechanics in Sports. Retrived from https://ojs.ub.uni-

konstanz.de/cpa/article/view/1952. 